\title{
ACHENE DIMORPHISM IN BIDENS PILOSA L. (ASTERACEAE) AS DETERMINED BY GERMINATION TEST
}

\author{
Adriana Amaral and Massanori Takaki* \\ Departamento de Botânica, UNESP - C.P. 199, Rio Claro - CEP 13506-900 - SP-Brasil
}

\begin{abstract}
The germination of achenes of Bidens pilosa L. was analyzed during the life span of the mother plant. Decrease in the range of achene size was monitored until the senescence of the mother plant when the shortest achenes were harvested. The analysis of the germination percentage confirmed the presence of two distinct classes, formerly defined as short and long ones. Because length can not be used for the separation of those classes, the morphological characteristics of the tegument, specially of the ornament must be used for separation of the achenes with verrucose tegument (formerly named as short achenes) and achenes without ornament of the tegument (formerly named as long achenes). The achenes with verrucose tegument presented dormancy and light sensitivity, and the achenes without ornament of the tegument presented no dormancy and no light sensitivity for the germination process.
\end{abstract}

Key words: Bidens pilosa, seed dimorphism, phytochrome, seed germination

\section{INTRODUCTION}

Bidens pilosa is a widelyspread weed responsible for decrease in the yield of several crops (FORSYTH \& BROWN, 1982). The presence of dimorphic achenes in Bidens pilosa has been described by several authors (FORSYTH \& BROWN, 1982; SANTRA et al.,1981). FENNER (1980), however, described the presence of polymorphic achenes, and CORKIDI et al. (1991) described about heteromorphic achenes in B. odorata.

FORSYTH and BROWN (1982), working with short and long achenes observed that short achenes presented dormancy and long ones germinated under light and darkness indicating no phytochrome control of the process. VALIO et. al. (1972) observed that light of different wavelength had no effect on achene germination and proposed that phytochrome was not involved in the process, but FENNER (1980) observed that the canopy filtered light induced photosensitivity for germination in B. pilosa. AMARAL and TAKAKI (1993) working with achenes of $B$. pilosa harvested in different places observed that the light sensitivity was present in different batches but short achenes always presented light sensitivity. In the present work we described the dimorphim of achenes in B. pilosa by germination tests.

* Corresponding author 


\section{MATERIAL AND METHODS}

Achenes of B. pilosa were harvested from plants during their life-span (120, 130, 150, 187 and 237 days). The achenes were measured with the aid of millimetered rule and eye piece.

Thirty achenes, on two layers of water moistened filter paper, in each of four $90 \mathrm{~mm}$ Petri dishes were used for germination test. The dishes were placed under continuous fluorescent light and under darkness by wrapping them with two layers of aluminum foil as described previously (AMARAL \& TAKAKI, 1993). Red light was obtained by filtering the fluorescent white light with two layers of red cellophane paper, and far-red light with the aid of two layers each of red and blue cellophane paper under incandescent bulb. The dark germinated achenes were counted under dim green safe light (KENDRICK \& FRANKLAND, 1969).

The germination percentage data were transformed in $\operatorname{arc} \sin \sqrt{X}_{\mathrm{X}}$ for analysis of variance (SNEDECOR, 1962). The distributions of achene sizes harvested in different periods were analysed and the least significant difference (LSD) determined at 5\% level of probability.

\section{RESULTS AND DISCUSSION}

We observed that the distributions of achene sizes during the life span of B. pilosa decreased from first achenes harvested where the range of size were $5-12 \mathrm{~mm}$ to $3-10 \mathrm{~mm}$ at achenes harvested in the senescent mother plants, i.e., after 237 days (Figure 1). The achenes were separated in two classes long and short ones by morphological characteristics (Figure 2). It was observed that achene considered as short presented verrucose ornament of the tegument, while achene considered as long presented no ornament. The LSD of mean achene sizes indicated significative difference among harvests (Table 1). This meant that the short achenes ( $5 \mathrm{~mm}$ long) of the first harvest was of the same size that the long achenes $(5 \mathrm{~mm}$ long) while short achenes were $3 \mathrm{~mm}$ long in the last harvest. 
Table 1. Mean achene sizes at different harvests

\begin{tabular}{|ccc|}
\hline Harvest (days) & $\mathrm{N}$ & Mean size \\
120 & 620 & $8,51 \mathrm{~A}$ \\
130 & 620 & $7,67 \mathrm{~B}$ \\
150 & 620 & $6,44 \mathrm{C}, \mathrm{D}$ \\
187 & 620 & $6,62 \mathrm{C}$ \\
237 & 620 & $6,10 \mathrm{D}$ \\
\hline
\end{tabular}

$\mathrm{N}=$ number of measured achenes

$\mathrm{LSD}=0,24$

Means with the same letter are not significantly different.
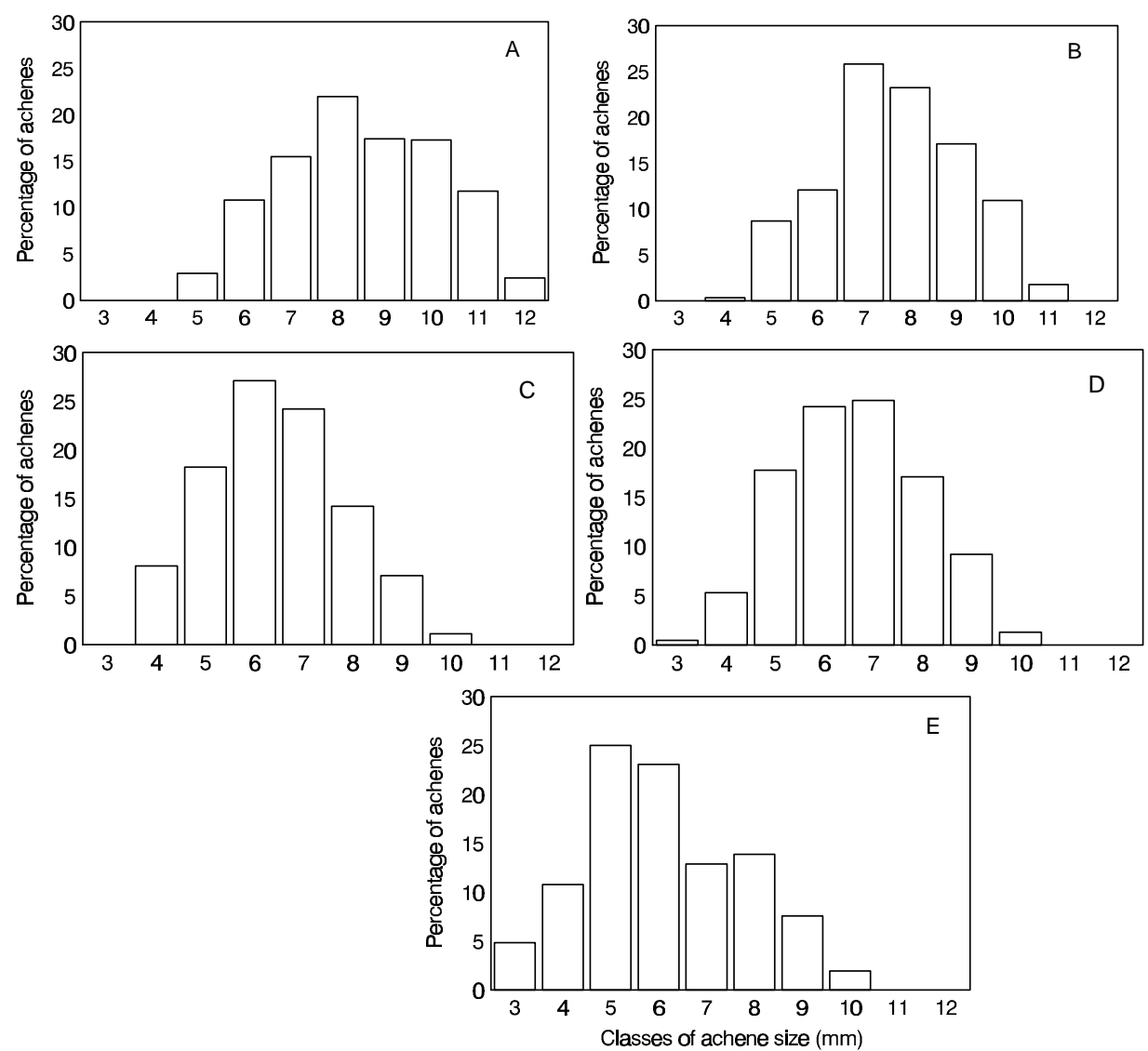

Figure 1. Distribution of achene sizes harvested in different ages of mother plant. A) 120 days; B) 130 days; C) 150 days; D) 187 days and E) 237 days.

The presence of polymorphic achenes has been reported by KOLLER and ROTH (1964) in Gymnarrhenna micrantha, by WULFF (1985) in Hyptis suaveolens and by 


\section{VENERABLE and LEVIN (1985) in Heterotheca latifolia.}

Germination test indicated that the achenes harvested after 120 days and ranging from 6 to $12 \mathrm{~mm}$ (achene without ornament) presented the same pattern of germination with no light sensitivity while $5 \mathrm{~mm}$ achenes (with ornament of the tegument) presented low germination and light sensitivity (table 2).

Tabela 2. Germination percentage of achenes of different sizes of Bidens pilosa harvested from 120 day-old plants and 150 days, under continuous white light and darkness.

\begin{tabular}{|c|c|c|c|c|}
\hline \multirow{2}{*}{ Achene length $(\mathrm{mm})$} & \multicolumn{2}{|c|}{120 day-old harvest } & \multicolumn{2}{|c|}{150 day-old harvest } \\
\hline & light & dark & light & dark \\
\hline 4 & - & - & $18.6 \mathrm{~b}$ & $6.6 \mathrm{c}$ \\
\hline 5 & $38.2 \mathrm{~b}$ & $7.5 \mathrm{c}$ & $96,6 \mathrm{a}$ & $97.5 \mathrm{a}$ \\
\hline 6 & $97.5 \mathrm{a}$ & $97.5 \mathrm{a}$ & $96.6 \mathrm{a}$ & $98.3 \mathrm{a}$ \\
\hline 7 & $98.3 \mathrm{a}$ & $98.3 \mathrm{a}$ & $100 \mathrm{a}$ & $97.5 \mathrm{a}$ \\
\hline 8 & $98.3 \mathrm{a}$ & $98.3 \mathrm{a}$ & $97.5 \mathrm{a}$ & $97.5 \mathrm{a}$ \\
\hline 9 & $96.6 \mathrm{a}$ & $97 \mathrm{a}$ & $98.3 \mathrm{a}$ & $98.3 \mathrm{a}$ \\
\hline 10 & $100 \mathrm{a}$ & $100 \mathrm{a}$ & $100 \mathrm{a}$ & $98 \mathrm{a}$ \\
\hline 11 & $100 \mathrm{a}$ & $100 \mathrm{a}$ & - & - \\
\hline 12 & $100 \mathrm{a}$ & $100 \mathrm{a}$ & - & - \\
\hline
\end{tabular}

means with the same letter are not significantly different

- achene not found in the indicated size

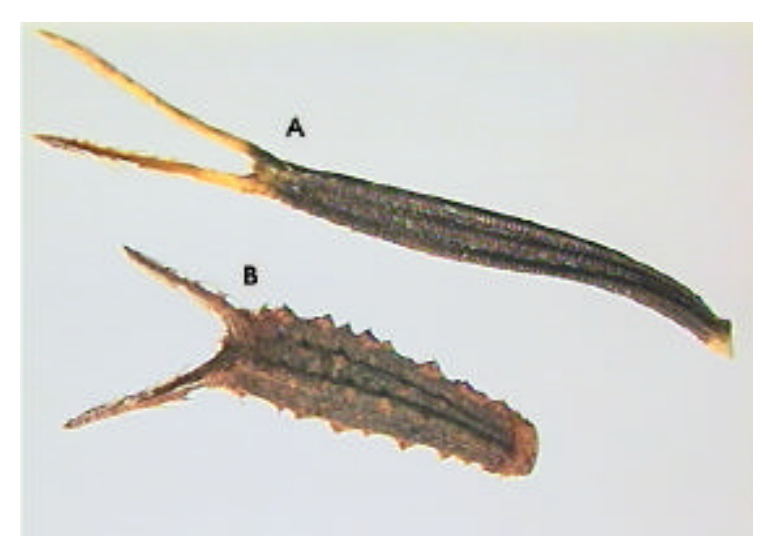

Figure 2. A. Achenes with ornament of the tegument (formerly named as long achene) and B. achene with verrucose ornament of the tegument (formerly named as short achene) of Bidens pilosa.

Achenes harvested from 150 days old plants presented the same pattern of germination. Short achenes now with $4 \mathrm{~mm}$ long presented dormancy and light sensitivity while long achenes $(5-10 \mathrm{~mm})$ presented no light sensitivity (Table 2). Due to the decrease in 
the range of achene size, the length could not be used to separate the two classes of achenes from a population of plants and morphological characteristics presented in the Figure 2 must be used for the separation of those classes.

FELIPPE (1990), working with B. gardneri observed the same pattern of dimorphism with dormant short achenes. CORKIDI et.al. (1991), working with achenes of B. odorata reported the presence of three classes for size distribution and proposed that phytochrome controlled germination in short and long achenes but not in achenes of intermediate size.

AMARAL and TAKAKI (1993) proposed that the germination of achenes of $B$. pilosa was controlled by phytochrome and the proportion of pre-existing Pfr (active form of phytochrome) was responsible for the germination in darkness.

The incubation of achenes under red and far-red light indicated that the germination of achenes without tegument ornament (formerly named as long achenes) were not controlled by phytochrome, however, achenes with verrucose ornament of the tegument (formerly named as short achenes) highest percentage germination was obtained under white and red lights, indicating phytochrome control (Figura 3). The achenes with verrucose ornament presented dormancy with the maximum percentage germination of $50 \%$ and the achenes without ornament of the tegument presented no dormancy.

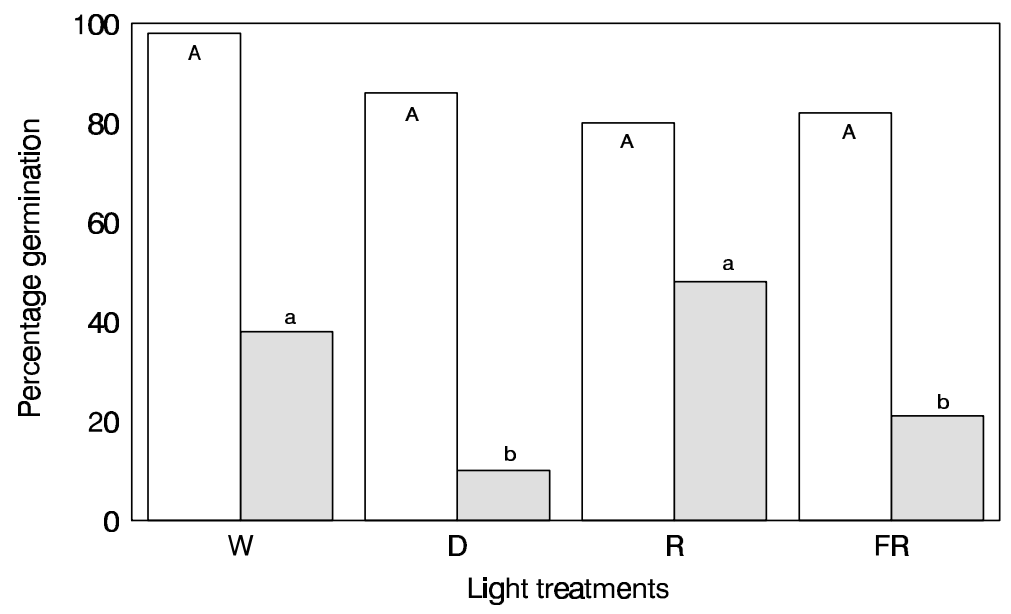

Figure 3. Effect of different light qualities on the germination of achenes without tegument ornament ( ) and achenes with verrucose ornament of the tegument (:") of B. pilosa incubated at $25^{\circ} \mathrm{C}$. The achenes were separated by morphological characteristics of the tegument ornament. $\mathrm{W}=$ white light, $\mathrm{D}=$ darkness, $\mathrm{R}=$ red light and $\mathrm{FR}=$ far-red light.

A,B- means with the same letter are not significantly different

a,b- means with the same letter are not significantly different 
Our results indicated that the achenes of B. pilosa were dimorphic, confirming FORSYTH and BROWN (1982) findings, although FENNER (1980) reported the presence of polymorphic achenes with the presence of a intermediate class, we suggest that the achenes must be separated only by morphological characteristics.

\section{ACKNOWLEDGEMENTS}

A.A. was supported by a CNPq fellowship and M.T. by a CNPq Research fellowship. This work was supported by grants from FAPESP, CNPq and FUNDUNESP. Thanks are due to Dr. Antonio C. S. Pião by statistical analysis.

\section{REFERENCES}

AMARAL, A.; TAKAKI, M. Germinação de sementes de espécies invasoras de culturas. III. Bidens pilosa L. Brazilian Archives in Biology and Technology, 38, 401-408, 1993.

CORKIDI, L.; RINCON, E.; VAZQUEZ-YANES, C. Effects of light and temperature on germination of heteromorphic achenes of Bidens odorata (Asteraceae). Canadian Journal of Botany, 69, 574-579, 1991.

FELIPPE, G.M. Germinação de Bidens gardneri Baker, uma planta anual dos cerrados. Hoehnea, 17, 7$11,1990$.

FENNER, M. The induction of a light requirement in Bidens pilosa seeds by leaf canopy shade. The New Phytologist, 84, 103-106, 1980.

FORSYTH, C.; BROWN, N.A.C. Germination of the dimorphic fruits of Bidens pilosa L. The New Phytologist, 90, 151-164, 1982.

KENDRICK, R. E.; SPRUIT, C.J.P.; FRANKLAND B. Phytochrome in seeds of Amaranthus caudatus. Planta, 88, 293-302, 1969.

KOLLER, O.; ROTH, N. Studies on the ecological and physiological significance of amphicarpy in Gymnarrhena micrantha (Compositae). American Journal of Botany, 51, 26-35, 1964.

SANTRA, S.C.; ADHYA, T.K.; DESARKAR, D.K. Ecological studies on Bidens pilosa L.: effect of light, temperature, salt and different extracts on seed germination and seedling growth. Tropical Ecology, 22, 163-169, 1981.

SNEDECOR, G.N. Statistical methods. Iowa: Iowa Sate University Press, 1962.

VALIO, I.F.M.; KIRSZENZAFT, S.L.; ROCHA, R.F. Germination of achenes of Bidens pilosa L. I. Effects of light of different wavelengths. The New Phytologist, 71, 677-682, 1972.

VENABLE, D.L.; LEVIN, D.A. Ecology of achene dimorphism in Heterotheca latifolia. I. Achene structure, germination and dispersal. Journal of Ecology, 73, 133-145, 1985.

WULFF, R.D. Germination of seeds of different sizes in Hyptis suaveolens. The response to irradiance and mixed red-far-red sources. Canadian Journal of Botany, 63, 885-888, 1985.

Received: 18 September 1997;

Revised: 26 May 1998;

Accepted: 20 July 1998. 